\title{
PRIMULA ALLERGIC DERMATITIS SIMULATING OCCUPATIONAL CONTACT DERMATITIS INDUCED BY METALS, OILS AND GREASES
}

\author{
MARTA KIEĆ-ŚWIERCZYŃSKA, BEATA KRĘCISZ, and DOMINIKA ŚWIERCZYŃSKA-MACHURA \\ Department of Occupational Diseases \\ Nofer Institute of Occupational Medicine \\ Łodź, Poland
}

\begin{abstract}
A case of the hands and face dermatitis in a patient employed in a store with motor-car spare parts is presented. Both the patient and her doctor were convinced that skin lesions were caused by the contact with metals, oils and greases. After detecting allergy to primine (after 48 and $96 \mathrm{~h},++$ ), the patient recalled that two months earlier she had started to grow primrose (Primula obconica) at home. Patch tests with the primrose leaf and flower were also positive $(++)$. The presented case provides evidence that routine primine testing is essential in all patients with suspected contact allergy dermatitis. In Poland like in the majority of countries, primina is not included in the standard kit.
\end{abstract}

Key words:

Primula, Primula obconica, Allergic contact dermatitis, Differential diagnosis

\section{CASE REPORT}

A 52-year-old woman without history of atopy employed in a shop with motor car spare parts for 15 years consulted a physician in the Department of Occupational Diseases. Three months earlier she developed hand dermatitis, af-

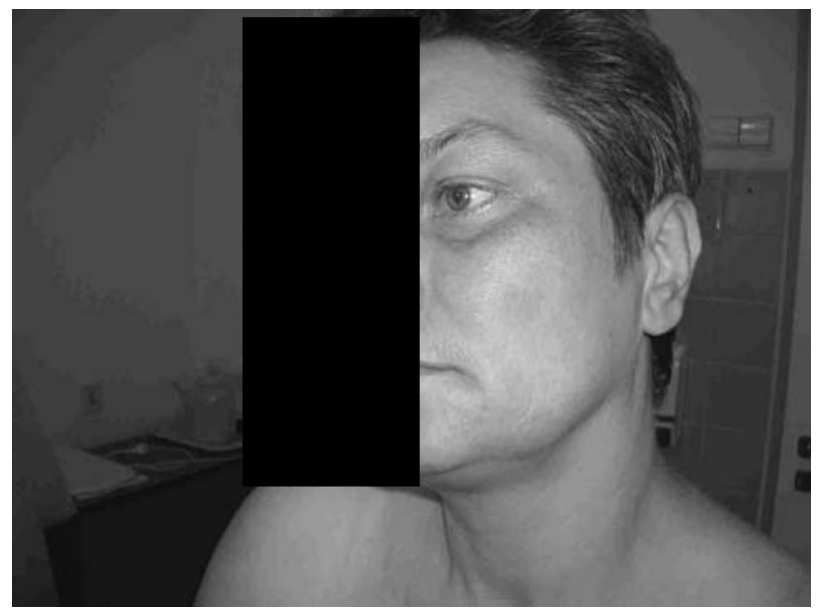

Fig. 1. Primula dermatitis faciei. fecting particularly the fingers (erythema, vesicles) and erythema with edema on the eyelids and cheeks (Figs. 1 and 2). The patient and her doctor were convinced that the dermal changes were due to contact with metals, lubricants or greases at her workplace. Therefore, she was

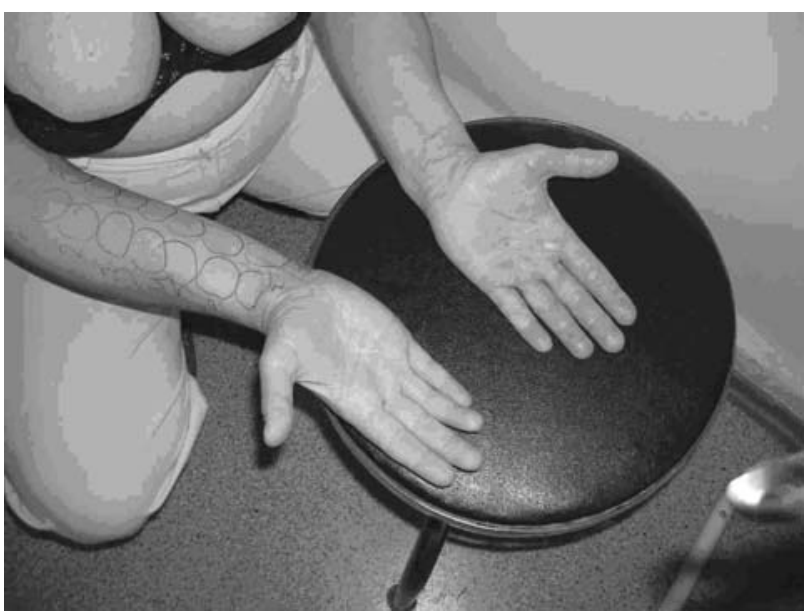

Fig. 2. Primula hand dermatitis.

Received: February 14, 2006. Accepted: February 27, 2006.

Address reprint requests to Prof. M. Kieć-Świerczyńska MD, PhD, Department of Occupational Diseases, Nofer Institute of Occupational Medicine, św. Teresy 8 , 91-348 Łódź (e-mail: marswier@imp.lodz.pl). 
Table 1. Patch test results

\begin{tabular}{lcc}
\hline & D2 & D4 \\
\cline { 2 - 3 } European Standard (Chemotechnique Diagnostics, & & \\
Malmö, Sweden) & & \\
Nickel sulfate (5\% pet.) & + & + \\
Primin $(0.01 \%$ pet.) & ++ & ++ \\
Oil \& Cooling Fluid Series (Chemotechnique & - & - \\
Diagnostics, Malmö, Sweden) & & \\
Our own materials & & \\
Leave of primula & ++ & ++ \\
Flower of primula & ++ & ++ \\
\hline
\end{tabular}

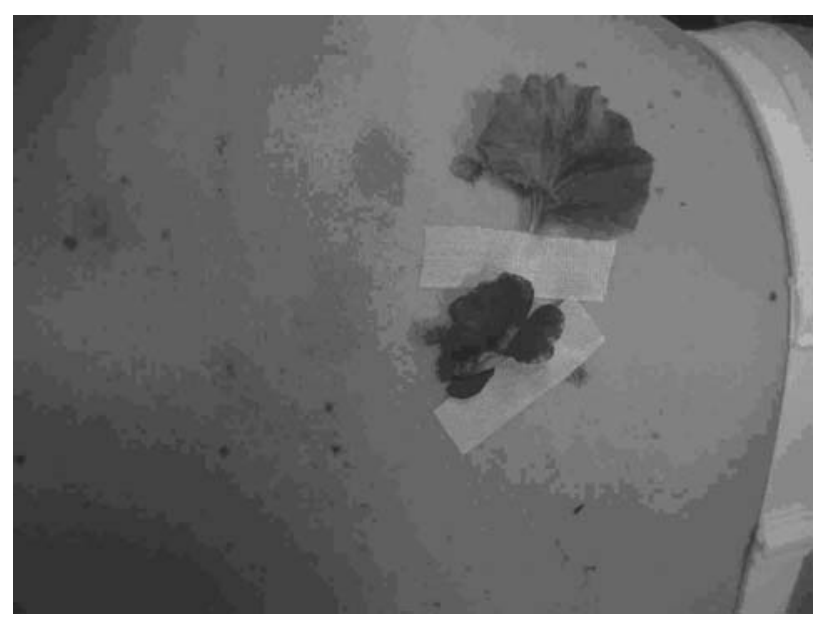

Fig. 3. Positive patch test with leave and flower of primula.

referred to the Nofer Institute of Occupational Medicine. The patient was patch-tested (Table 1). When she was informed that she was primin-positive, she recalled that 2 months before the detection of the dermal changes she had brought home a primula (Primula obconica). She was additionally patch-tested with primula leaf and flower. After 48 and 96 h, the tests were positive (++) (Fig. 3). The plant was removed from the patient's home and the dermal symptoms considerably receded.

\section{DISCUSSION}

The primula allergen is contained in glandular hairs located on the surface of leaves, stems and flowers. Patients have linear streaks of erythema and vesicles on the forearms, hands, and face. Sometimes the changes are non typical (erythema multiforme, pompholyx, seborrheic dermatitis, herpes simplex) [1,3-5].

We report this case to illustrate a high likelihood of misdiagnosis. The location and character of the dermal changes could suggest an occupational origin of the disease, while the patient herself failed to note the adverse effect of the contact with the plant grown at home. Besides, the case points to the necessity for primin testing of all patients with suspected allergic contact dermatitis. In Poland like some other countries, primina is not included in the standard allergen set.

\section{REFERENCES}

1. Tabar A I, Quirce S, Garcia B E, Rodrguez A, Obliguibel J, M. Primula dermatitis: versatility in its clinical presentation and the advantages of patch tests with synthetic primin. Contact Dermatitis 1994;30:47-8.

2. Aplin CG, Lovell CR. Contact dermatitis due to hardy primula species and their cultivars. Contact Dermatitis 2001;44:23-9.

3. Nakamura T. Primula dermatitis in Japan. Contact Dermatitis 1983;9:63-4.

4. Virgili A, Corazza M. Unusual primin dermatitis. Contact Dermatitis 1992;24:63-4.

5. Thomson KF, Charles-Holmes R, Beck MH. Primula dermatitis mimicking herpes simplex. Contact Dermatitis 1997;37:185-6. 